\title{
A CONSTRUÇÃO DA FORMAÇÃO DOCENTE DE LICENCIADAS EM PEDAGOGIA NOS PRIMEIROS ANOS DE MAGISTÉRIO.
}

\author{
THE CONSTRUCTION OF THE TEACHING TRAINING OF LICENSES IN \\ PEDAGOGY IN THE FIRST YEARS OF MAGISTÉTIO.
}

\section{Renata Beatriz Ronchi Zapelini ${ }^{1}$ Samira Casagrande ${ }^{2}$}

\begin{abstract}
RESUMO: O presente artigo objetiva compreender como se constrói a formação inicial docente das professoras pedagogas nos primeiros anos de licenciadas. Para além do estudo bibliográfico o trabalho conta com pesquisa de campo, em que foi analisado sete professoras pedagogas que atuam nos municípios de Criciúma e Içara/SC, tanto em rede pública como privada. A entrevista foi semiestruturada, uma vez que permitiu ir além do roteiro planejado. A análise de dados possibilitou um comparativo com o referencial teórico e por meio desse, observou-se a necessidade de uma proximidade com a escola durante a graduação, permitiu identificar a carência de conhecimentos pertinentes a profissão e também, certo descaso por parte da gestão e dos professores com mais tempo de escola, para com as pedagogas recémchegadas. Tal situação indicou a urgência de se promover diálogos, buscando contribuir com a tomada de consciência dos professores mais experientes, para que esses percebam quão prejudicial é o descuido para com as professoras que estão iniciando. $\mathrm{O}$ artigo busca ainda, contribuir para a compreensão da contínua busca por conhecimento, visto que, o conhecimento pode ser uma ferramenta de transformações, tanto de cunho profissional como também pessoal.
\end{abstract}

PALAVRAS CHAVE: Formação inicial e continuada. Didática. Tendência pedagógica.

ABSTRACT: The present article aims to understand how the initial teacher education of pedagogical teachers is built in the first years of the graduates. In addition to the bibliographic study, the work has field research, in which seven pedagogical teachers who work in the municipalities of Criciúma and Içara / SC, in both public and private schools, were analyzed. The interview was semi-structured, since it allowed to go beyond the planned script. Data analysis enabled a comparison with the theoretical framework and through this, it was observed the need for a proximity to the school during graduation, allowed to identify the lack of knowledge relevant to the profession and also, a certain disregard on the part of the management and of the teachers with more time of school, to the new arrivals pedagogues. Such situation indicated the urgency of promoting dialogues, seeking to contribute to the

\footnotetext{
${ }^{1}$ Graduada em Pedagogia. renataronchi@hotmail.com

${ }^{2}$ Mestre em Educação. Universidade do Extremo Sul Catarinense sca@unesc.net Saberes Pedagógicos, Criciúma, v. 4, n¹, janeiro/abril 2020.-Curso de Pedagogia- UNESC
} 
awareness of the most experienced teachers, so that they realize how harmful is the neglect of the teachers who are starting. The article also seeks to contribute to the understanding of the continuous search for knowledge, since knowledge can be a tool for transformations, both professional and personal.

KEYWORDS: Initial and continuing training. Didactics. Pedagogical trend.

\section{INTRODUÇÃO}

Durante minha formação acadêmica no curso de Pedagogia, tive a oportunidade de me inserir em algumas instituições de ensino, por meio do estágio obrigatório e não obrigatório, no qual pude perceber que nas escolas os professores efetivos, os temporários e recém-formados, dividem o mesmo ambiente. Nessa ocasião atentei-me a forma com que os professores mais experientes reagem em relação aos recém-formados.

Neste contexto, inquietações permearam meus pensamentos, o que me fez refletir acerca de possíveis resultados decorrentes de tais reações na vida profissional das recémformadas. Será que é realizado orientação pedagógica a esta recém-formada chegada à escola? De que maneira a mesma se percebe junto aos pares da instituição? Será que a falta de vínculo entre professora/escola e professor/professor, prejudica a atuação profissional?

Além de questionar-me se a chegada dessa pedagoga era visto como algo de pouca relevância, perguntei-me também se suas dificuldades nesse período inicial, eram entendidas como parte das responsabilidades da escola? A escola deve ou não instruí-la, acerca da rotina interna, do perfil da turma com a qual irá desenvolver seu trabalho, dos horários pertinentes, até a apresentação do cronograma anual?

Assim, refletindo sobre os conhecimentos adquiridos ao longo dos anos de formação acadêmica, em que por meio de teoria e prática foi compreendido que o sujeito deve ser visto em sua integralidade e respeitado em suas diferenças, procurei buscar respostas a esses questionamentos. Entendo que a pedagoga recém-formada traz consigo, além de todos os conhecimentos apreendidos durante o seu período de formação acadêmica, suas inseguranças, anseios e medos, sobre a prática docente. Assim, por compreender que nos 
primeiros anos de atuação se estabelece um período de construção, e reconstrução de conhecimento profissional, é que se faz essa pesquisa.

Para tanto, a problemática desta pesquisa, se traduz em saber de que forma se constrói a formação inicial docente das professoras pedagogas nos primeiros anos de licenciadas. Consoante ao disposto, apresenta-se como objetivo geral compreender como se constrói a formação inicial docente das professoras pedagogas nos primeiros anos de licenciadas, e como objetivos específicos, conhecer como ocorreu a formação continuada das pedagogas; constatar se há suporte didático à pedagoga recém-formada; descrever como a mesma se percebe junto aos pares da instituição e por fim investigar como as pedagogas avaliam seu curso de formação.

Diante disto esta pesquisa pretende contribuir no sentido de proporcionar uma reflexão por parte da gestão escolar e dos professores atuantes na educação, a fim de que analisem a relevância da recepção, estabelecimento de vínculo e orientação direcionada as professoras recém-formadas, ofertando um suporte pedagógico oportunizando as trocas de experiências, favorecendo assim o estreitamento de laços e contribuindo na sua atuação inicial.

\section{FORMAÇÃO INICIAL DOCENTE OU DOCENTE EM CONSTANTE FORMAÇÃO?}

Compreende-se que o início da vida profissional docente é um período em que incertezas e inseguranças estão presentes. Os sujeitos, ao se inserirem no ambiente escolar, se deparam com pluralidades de conhecimentos. Esses, por sua vez, podem contribuir em sua formação, pois é no exercício da ação docente que emerge as especificidades da profissão. Tardif (2002, p. 230) entende que,

[...] um professor de profissão não é somente alguém que se aplica conhecimentos produzidos por outros, não é somente um agente determinado por mecanismos sociais: é um ator no sentido forte do termo, isto é, um sujeito que assume sua prática a partir dos significados que ele mesmo lhe dá, um sujeito que possui conhecimentos e um saber-fazer provenientes de sua própria atividade e a partir dos quais ele a estrutura e a orienta.

Saberes Pedagógicos, Criciúma, v. 4, nº 1, janeiro/abril 2020.- Curso de Pedagogia- UNESC 
Dessa forma, mesmo suscetível a esses sentimentos decorrentes do período transitório, de início de uma carreira profissional onde, de acadêmico/a assume a função docente, o professor é produtor ativo de saberes. Segundo o autor, estes saberes são constituídos de diferentes formas.

A construção da formação do professor ocorre por meio da interação com seus pares e seus alunos; da pedagogia institucionalizada, das suas emoções, de sua inteligência, de sua própria experiência de vida, logo, a dicotomia entre o pessoal e o profissional torna-se algo inconcebível. Nesse sentido o autor argumenta que:

[...] no âmbito dos ofícios e profissões, não creio que se possa falar do saber sem relacioná-los com os condicionantes e com o contexto do trabalho: o saber é sempre o saber de alguém que trabalha alguma coisa no intuito de realizar um objetivo qualquer. Além disso o saber não é uma coisa que flutua no espaço: o saber dos professores é o deles e está relacionado com a pessoa e a identidade deles, com a sua experiência de vida e com a sua história profissional, com as suas relações com os alunos e em sala de aula e com os outros atores escolares na escola, etc. (TARDIF, 2002, p. 11)

Na perspectiva do referido autor, a produção de conhecimento deve estar a serviço da formação, para que essa venha contribuir com a transformação de pensamentos e atitudes. Logo, Tardif (2002) entende que, para alcançar os objetivos almejados, o docente faz uso de diferentes saberes, com os quais mantem diferentes relações. Sendo estes: "Os saberes da formação profissional (das ciências da educação e da ideologia pedagógica)", "Os saberes disciplinares", "Os saberes curriculares" e os "Os saberes experienciais" (TARDIF, 2002, p. 36,38). A seguir apresenta-se a compreensão destes saberes a partir da visão de Tardif (2002):

Os "saberes da formação profissional" são um conjunto de conhecimentos pedagógicos, legitimado cientificamente, que ocorre dentro das instituições de ensino, de forma inicial ou continuada, com o objetivo de oferecer técnicas e métodos de ensino (saberfazer).

Já os "saberes disciplinares" são os que foram acumulados e produzidos ao longo do tempo pela humanidade, sendo geridos pela comunidade científica, oriundos dos vários campos do conhecimento, história, ciências humanas, matemática, etc. Esses saberes são passados dentro das universidades e faculdades.

Saberes Pedagógicos, Criciúma, v. 4, nº 1, janeiro/abril 2020.- Curso de Pedagogia- UNESC 
Enquanto que os "saberes curriculares" são as formas com que as universidades administram os conhecimentos socialmente produzidos que devem ser trabalhados junto aos estudantes. Também identificados com objetivos, conteúdos, métodos para que professores possam saber aplicar.

Os "saberes experienciais" são resultados das suas práticas diárias, derivam das relações e acontecimentos vividos pelos docentes no exercício de sua função, se originam também das relações com seus pares e alunos. Estes saberes são práticos, por isso não advém dos currículos ou das instituições de ensino.

Para Tardif (2002) é na prática docente que nascem os saberes experienciais, uma vez que é no exercício de sua atividade que o docente se depara com situações diversas, as quais faz uso de seus conhecimentos para resolvê-las, por isso, estes saberes são produzidos internamente, ou seja, na prática.

Neste sentido, Nóvoa (2009, p. 17) traz importantes contribuições ao referido tema, formação docente, que tem sido muito discutido nos últimos tempos. Segundo o autor, a forma como os professores conduzem seu trabalho tem relação direta com a sua formação enquanto sujeito, assim a íntima relação do ser e do fazer constituem o professor.

Nóvoa (2009), destaca que muitas são as características que podem definir o bom professor. Não existe uma fórmula única, em que os profissionais que queiram ser bons professores, possam se enquadrar, tendo em vista a pluralidade que constitui os sujeitos.

Dentre as caraterísticas que podem representar um bom professor Nóvoa (2009) destaca o conhecimento, já que para ensinar é necessária a fundamentação científica que conduzirá os alunos à aprendizagem. Outra característica é o que o autor chama de cultura profissional, onde se enquadra a compreensão da rotina escolar, aqui o profissional necessita compreender como funciona a escola. $\mathrm{O}$ ato pedagógico, refere-se a compreender os sujeitos além do ensinar e aprender. $\mathrm{O}$ autor menciona inclusive o trabalho em equipe, defendendo uma ação pedagógica colaborativa, que vai além da escola. Por último destaca o compromisso social, que corresponde ao papel social do educador, em construir valores e hábitos, que ultrapassam o contexto escolar.

Diante disto, Nóvoa (2009) propõe que estas características possam fundamentar e inspirar programas de formação de professores, sugerindo que, para uma reformulação e

Saberes Pedagógicos, Criciúma, v. 4, nº 1, janeiro/abril 2020.- Curso de Pedagogia- UNESC 


\section{SABERES PEDAGÓGICOS}

Revista do Curso de Graduaçăo de Pedagogia - Unesc

ISSN 2526-4559

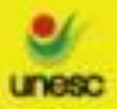

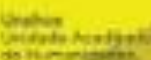

qualificação da profissão, se fazem necessárias mudanças que vão desde a formação inicial até a atuação profissional. Assim, a formação do professor deve passar para dentro da profissão, em que professores mais experientes possam ser formadores dos iniciantes, como ocorre, segundo o autor com os profissionais da medicina onde todos os envolvidos "(chefe da equipe, médicos, internos, estagiários, etc.)” Nóvoa (2009, p. 5), sem que haja inversão de papeis, colocam-se em análise constante para êxito profissional.

Para Nóvoa (2009) uma formação docente de qualidade requer um estudo aprofundado, no qual necessite ir além da graduação, do mestrado ou doutorado, deve ser uma formação contínua, onde possam ser criadas situações que possibilite ao professor ser pesquisador, observando, analisando e propondo soluções aos casos de sucesso e de insucesso escolar.

Do mesmo modo a formação necessita considerar os professores enquanto sujeitos inteiros, que carecem de reflexão constante entre o ser e o fazer. Formar professores que se integrem aos projetos educativos, dialogando com os outros profissionais em constante troca. Com isso o autor propõe a valorização dos assuntos especificamente escolares, sendo divulgados por profissionais da educação, em que o professor venha a ter "voz nos debates públicos" (NÓVOA, 2009, p. 8).

Diante do exposto pode-se perceber, segundo os autores, Tardif (2002) e Nóvoa (2009), que atualmente há um distanciamento entre a formação e a exigência educativa atual, uma vez que não se considera a subjetividade dos docentes, sendo que situações diárias enfrentadas por docentes requerem habilidades pessoais para solucioná-las, habilidades estas que não são ensinadas na graduação, que seria os "saberes experienciais", conforme Tardif (2002).

Com isso, as injunções apresentadas por Tardif (2002) e Nóvoa (2009) são fundamentais para modificar este cenário, tendo em vista que ambos consideram a importância de compartilhar os saberes da profissão docente como elemento substancial da prática e, reafirmam ainda, sobre a necessidade de uma reformulação na formação docente, de forma que atenda às necessidades tanto do professor como também da sociedade. 


\section{SABERES PEDAGÓGICOS}

Revista do Curso de Graduaçāo de Pedagogia - Unesc

ISSN 2526-4559

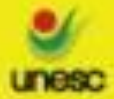

ationiones

$\mathrm{Na}$ constituição dos saberes da docência, estão implícitos ou explícitos a visão de homem, mundo e sociedade que embasam as práticas dos professores. Essas visões denominam-se tendências pedagógicas, que devido a sua importância serão detalhado abaixo.

\subsection{As tendências pedagógicas e seus pressupostos filosóficos e metodológicos.}

Ainda no campo de formação docente é necessário analisar as tendências pedagógicas, para Libâneo (1993) a prática pedagógica adotada pelo educador, demonstra sua visão de mundo, sua concepção sobre o papel da educação frente à transformação social, política e cultural, enfim, suas convicções, de homem e de mundo.

Assim, o autor apresenta as tendências pedagógicas classificando-as em dois grupos. O primeiro grupo, é o liberal, composto por Pedagogia Tradicional, Pedagogia Renovada e o Tecnicismo educacional. O segundo grupo, é o progressista, que se constitui pela Pedagogia Libertadora, Libertária e a Pedagogia Crítico Social dos Conteúdos.

As características marcantes da Pedagogia Tradicional segundo Libâneo (1993) é a transmissão de conteúdo sem questionamentos, e, por vezes, desvinculada da realidade social e do interesse dos educandos. O professor é o protagonista, ele expõe e interpreta as matérias por meio da oralidade, impõe o silêncio com regras e castigos. Na Pedagogia Tradicional entende-se, segundo o autor, que a aprendizagem ocorre por meio da memorização, e para isso o silêncio é obrigatório.

O educando é um receptor passivo. Compete a ele prestar atenção ao que o professor expõe e resolver uma série de exercícios repetitivos a fim de que a memorização ocorra. Para verificar se o aluno "gravou" são aplicadas provas escrita ou oral, e as respostas tem que ser compatíveis com a fala do professor.

A escola nessa tendência tem como propósito a formação do aluno ideal, e desse modo, entende que sua responsabilidade é de, transmitir a cultura, as grandes descobertas do homem, formar raciocínio lógico, treinar a mente e a vontade do aluno.

Ainda dentro do grupo das tendências liberais, surge a Pedagogia Renovada, que embora esteja no campo liberal percebe-se a oposição em relação à Pedagogia Tradicional. Segundo Libâneo (1993), o professor aqui, não é o foco, e, sim um facilitador, aquele que

Saberes Pedagógicos, Criciúma, v. 4, nº 1, janeiro/abril 2020.- Curso de Pedagogia- UNESC 
ajuda o aluno a aprender, por meio de uma relação autêntica e pautada no respeito, orientando, incentivando e organizando situações de aprendizagem que possibilitem satisfazer o interesse, tanto do aluno quanto o da sociedade. Para isso, o educador é adepto a técnicas como, trabalho em grupo, estudo individual, pesquisas, projetos entre outros.

De acordo com o autor, a Pedagogia Renovada, é centrada no aluno, valoriza a ideia do aprender fazendo, assim coloca o aluno frente a experiências e situações que tenham que solucionar problemas. Desse modo não é o fazer por fazer, e sim acionar a capacidade intelectual, a escrita, expressão verbal, entre outras atividades intelectuais do aluno. Assim, a escola deve adequar as necessidades individuais do sujeito ao meio em que este está inserido, de forma que retrate a realidade social quando possível.

Por fim, ainda dentro do campo liberal, o tecnicismo educacional, que ganha força por volta dos anos 60, segundo Libaneo (1993), essa orientação foi imposta as escolas pelo regime militar, por ser compatível na área econômica, política e ideológica desse governo.

Ao professor cabe o papel de organizar um planejamento eficiente, contendo etapas bem definidas, com objetivos, conteúdos e estratégias, para então executar o programa de ensino. Por fim, o professor por meio de avaliação deve averiguar se foi atingido o objetivo proposto.

Ainda segundo o autor, o aluno é um receptor que deve memorizar as informações de forma passiva e reproduzi-las. A escola tem a função preparar o educando para se adequar ao meio, assim como nas tendências anteriores. Para Libâneo (1993) a pedagogia liberal entende que a função da escola é preparar o sujeito para adequar-se à sociedade, seus valores e regras vigente, ignorando as desigualdades sociais e dando ênfase a cultura acumulada pelo homem.

Com a mudança no quadro político do país na segunda metade da década de 70 , torna-se possível, segundo Libâneo (1993), que alguns estudiosos e militantes políticos discutissem uma escola ligada a realidade e necessidade do povo. É o que o autor classificou como Pedagogia Libertadora que pertence ao grupo de cunho progressista.

Dessa forma, o professor assume o papel de organizador de temas e atividades, sua relação com os alunos é horizontal, uma relação de igualdade no que se refere ao conhecimento. O professor ao ensinar também aprende, e o aluno ao aprender também ensina.

Saberes Pedagógicos, Criciúma, v. 4, nº 1, janeiro/abril 2020.- Curso de Pedagogia- UNESC 
Quanto aos educandos, estes têm papel importante, uma vez que por meio de sua participação, no "processo em que se realiza a discussão, os relatos da experiência vivida, a assembleia, a pesquisa participante, o trabalho em grupo etc.” (LIBÂNEO, 1993, p. 69), surge o que o autor denomina temas geradores. Estas, situações problemas, que os próprios educandos levantaram, é que irão direcionar as aulas.

Essa tendência foi bem aceita por ser vivenciada por sujeitos ligados a mobilizações sociais e conduzida por teóricos comprometidos com a realidade social; porém, não foi aplicada "orientação pedagógico-didática especificamente escolar", que atenda a idade cronológica, o desenvolvimento cognitivo dos alunos, que são crianças e jovens. (LIBÂNEO, 1993, p. 69).

Outra tendência dentro do grupo progressista é a Libertária. Aqui o educador se coloca em posição de orientador, instrutor, sempre disposto a contribuir com o grupo, mas sem impor ideias e conceitos, nesta tendência o poder e o autoritarismo não são aceitos.

Ainda de acordo com Libâneo (2001), os alunos são participativos e tem o poder de decisão na escolha do que irão estudar, que tipo de atividade irão realizar, embora já tenha um conteúdo definido, a escolha de qual será estudado é feita pelo grupo.

A escola compete à missão de transformar a visão de mundo dos alunos, fazendo com que eles se percebam parte vital para mudanças de todo e qualquer sistema imposto pelo Estado, para isso a escola cria mecanismos como assembleias, conselhos e reuniões, na intenção de criar uma identidade participativa e mobilizadora no aluno, fazendo com que decidam o que deve ser discutido, assim, segundo Libâneo (2001), pode-se entender como uma educação autogestionária.

Já a Pedagogia Crítico-Social dos Conteúdos, coloca o educador na posição de mediador entre o conhecimento cientifico e o saber do aluno. O professor tem o importante papel de motivador crítico da aprendizagem, pois levará os educandos a refletirem acerca dos conteúdos em confronto com as realidades sociais. Segundo Libâneo (2001), o professor deve organizar seu trabalho levando em conta as características dos alunos, buscando compreender como esses sujeitos pensam e vivem sua realidade. O professor deve ter total domínio dos conteúdos que trabalha, buscando refletir a realidade vivenciada pelo aluno, e assim favorecer os questionamentos. Essa participação possibilitará o interesse de novos conhecimentos e com

Saberes Pedagógicos, Criciúma, v. 4, nº1, janeiro/abril 2020.- Curso de Pedagogia- UNESC 
isso o professor pode "[...] despertar outras necessidades, acelerar e disciplinar os métodos de estudo [...]” (LIBÂNEO, 2001, p. 41). Por meio do domínio dos conteúdos científicos, hábitos e habilidades, o aluno tende a desenvolver um pensamento crítico frente à realidade social, e dessa forma segundo Libâneo (1993), pode assumir uma postura de agente ativo e transformador colaborando para as mudanças sociais, caso perceba a necessidade.

A escola não pode estar alheia à realidade social, os conhecimentos sistematizados e acumulados pela humanidade são valorizados dentro dessa perspectiva, porém a escola deve estar sempre refletindo qual o papel desses conteúdos frente à sociedade, desse modo, os conhecimentos sistematizados, devem ser contextualizados. Assim os conteúdos devem ser relacionados à realidade dos alunos, fazendo com que eles desenvolvam suas capacidades intelectuais e reflexivas, tendo em vista a complexidade do mundo moderno. Para Libâneo (2001) cabe à escola fazer com que essas informações sejam questionadas e confrontadas com a realidade para que haja conhecimento, pois por meio do conhecimento é que se busca a superação das desigualdades sociais. Desse modo, percebe-se a distinção entre os referidos grupos, sendo que o grupo liberal atua no sentido de manter a ordem vigente enquanto que a pedagogia crítico-social dos conteúdos apresenta, segundo o autor, a intenção de interferir e transformar a realidade social.

Importa saber que a Proposta Curricular de Santa Catariana (2014) e de Criciúma (2008), assume em seus pressupostos filosóficos e metodológicos a tendência pedagógica crítica social dos conteúdos, pautada principalmente nas ideias de Vygotsky. Apesar de que essas ideias expressam uma teoria de aprendizagem e não uma tendência pedagógica, elas visam uma compreensão sobre as transformações dos processos de ensino, da aprendizagem e do desenvolvimento humano.

Neste sentido, tendo em vista a diversidade de tendências pedagógicas e suas intencionalidades se faz necessário que o educador as conheça e fundamente seu trabalho para o exercício de sua prática pedagógica. Dada à relevância do conhecimento acerca das tendências pedagógicas e tudo que ela implica no fazer pedagógico, se faz oportuno evidênciar a contribuição da didática e da formação continuada frente ao docente em sua vida profissional. 


\section{SABERES PEDAGÓGICOS}

Revista do Curso de Graduaçāo de Pedagogia - Unesc

ISSN 2526-4559

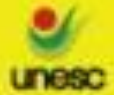

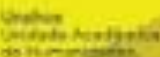

\subsection{Didática e a formação inicial e continuada de professores.}

A didática, surge em um momento importante para a educação, período em que buscava-se estender o direito a educação para todos. O responsável por esse ideal segundo Pimenta (2013) foi Comenius, por meio da "Carta Magna", criou um método universal que prometia ensinar tudo a todos. A ideia de ensino/aprendizagem estava vinculada a forma mais fácil e duradoura de aprender. Entretanto, a didática não pode ser concebida somente como a "arte de ensinar", ela é mais que isso. Logo, há de se pensar os momentos históricos da educação e o papel da didática frente a esses momentos.

Para Libâneo (1993, p. 28), “[...] a didática se caracteriza como mediação entre as bases teórico-científicas da educação escolar e a prática docente. Ela opera como uma ponte entre o "o que" e o "como" do processo pedagógico escolar."

Corroborando com esta ideia, Pimenta (2013, p. 4), diz que, "a didática, como área da pedagogia, estuda os fenômenos de ensino", haja vista, que o ensino pode ser entendido como um ato político e intencional, em que o professor expressa sua visão de homem, desse modo, parece oportuno refletir sobre a didática:

[...]como campo específico de conhecimento, tem uma responsabilidade social de acompanhar e refletir as mudanças que ocorrem no mundo e dar respostas para a ressignificação dos processos de ensino na perspectiva da aprendizagem do aluno. (PIMENTA, 2013, p.150).

É preciso pensar o papel da didática frente ao atual momento educacional, em que se busca a apropriação dos conhecimentos socialmente construídos e sua sistematização com os saberes teóricos produzidos cientificamente. Assumindo esta perspectiva, Libâneo (2001), afirma que cabe a didática ser mediadora do ensinar do professor e do aprender do aluno, fazendo assim, uma "ressignificação" do saber disciplinar e sistematizado.

Consequentemente o papel que cabia a didática acerca de 355 anos, em seu nascimento, não é o mesmo nos dias atuais, pois hoje, segundo Libâneo (1993), se objetiva por meio da educação, contribuir com formação de sujeitos críticos, emancipados e questionadores, dentro do conceito de Pedagogia Crítico-Social dos Conteúdos. Dessa forma,

Saberes Pedagógicos, Criciúma, v. 4, nº 1, janeiro/abril 2020.- Curso de Pedagogia- UNESC 


\section{SABERES PEDAGÓGICOS}

Revista do Curso de Graduaçāo de Pedagogia - Unesc

ISSN 2526-4559

a didática como ferramenta de mediação entre o ensinar e o aprender, tem propósito de dar sentido ao conhecimento.

Tendo em vista, a função da didática dentro dessa perspectiva, Pimenta (2013, p. 150) faz uma reflexão, [...] como a didática pode tornar possível o ensino? Um ensino que proceda à mediação reflexiva entre os valores e a cultura que a sociedade dissemina e os estudantes em formação? Pode ela sozinha dar conta dessa tarefa? A autora é enfática ao deduzir que não, contudo, sendo uma área especifica do conhecimento, deve refletir a práxis educativa, no sentido de questionar o objetivo do ensino, tendo ampla análise do processo de ensino e aprendizagem.

Ademais, Libâneo (1998) diz que, tudo que se propõe trabalhar com os alunos, deve primeiramente ser de domínio do professor. Assim, quando se fala em contribuir para formação de um sujeito crítico e reflexivo, o professor também o deve ser. Agora para que isso seja uma constante na realidade profissional do educador, ele não deve limitar sua formação a formação inicial, o processo de conhecimento é contínuo e indispensável a todos os sujeitos, mas principalmente ao professor, para que assim ele possa estar em permanente reflexão de sua prática profissional. E uma maneira de atualizar-se é por meio da formação continuada.

Sendo que, a formação continuada deve capacitar o educador a apropriar-se do que Libâneo (1998, p. 06) chama de "Sólida cultura geral”, sendo esta a capacidade de olhar a sua volta, um olhar investigador, para compreender as realidades "econômicas, sociais e culturais". De modo a perceber os interesses de classe, refletir, posicionar-se frente às questões postas publicamente sobre a educação no país. Possibilitando melhorar as "condições de ensino, para os interesses majoritários da população".

Ainda sobre as competências da formação continuada, essa deve contribuir para o domínio dos conhecimentos sistematizados, a cultura acumulada do decorrer da história e compartilhado com os alunos nos espaços escolares. Para Libâneo (1998), o professor na condição de "mediador" deve ter entendimento e domínio desses conteúdos e a partir deles fazer uma correlação com realidade concreta e atual.

Refletindo acerca dessa condição de "mediador" ao qual Libâneo (1998) se referiu, e ao lembrar da injunção de Pimenta (2013), em que a autora afirma que, ensinar é 
uma tarefa complexa, a busca por capacitação torna-se imprescindível, pois a formação continuada pode servir de instrumento mediador do desenvolvimento cognitivo e pedagógico do docente.

Nesse segmento, um dos instrumentos de formação continuada para Nóvoa (2017), pode ser a reflexão individual e conjunta das práticas que norteiam o trabalho docente, visando acompanhar as frequentes mudanças que a educação passa. Segundo o autor, a troca de informações e experiências vivenciadas no interior das salas de aula, contribui para superar as adversidades que se apresentam no exercício da profissão docente, e assim, fazer contribuir para que haja ensino/aprendizagem.

Assim, com o professor em constante formação, trocando experiências e como Pimenta (2013) destaca, reformulando a didática, pode ser possível reformar a prática educativa e desenvolver um ensino que possa promover igualdade de acesso e permanência a todos os alunos.

\section{METODOLOGIA, APRESENTAÇÃO E ANÁLISE DE DADOS}

Esta pesquisa objetiva compreender como se constrói a formação inicial docente das pedagogas nos primeiros anos de licenciadas. Constitui em sua metodologia uma abordagem qualitativa a fim de responder ao problema de pesquisa, que para Gil (2002, p. 42) "O objetivo fundamental da pesquisa é descobrir respostas para os problemas mediante o emprego de procedimentos científicos". Sendo de natureza básica, pois tem o propósito de solucionar inquietações encontradas durante o estágio não obrigatório da pesquisadora, além de ampliar os conhecimentos adquiridos na graduação. Para isto, realizou-se estudo bibliográfico, buscando aprofundar os referenciais teóricos e comparar com as respostas das entrevistadas. Também foi feito uma pesquisa de campo para coleta de dados, com entrevista semiestruturada, sendo que segundo Gil (2002), a entrevista proporciona maiores possibilidades, podendo ser encontrada como entrevista informal, focalizada, totalmente estruturada e semiestruturada. Dessa forma, optou-se por entrevista semiestruturada, uma vez que esta torna possível maior exploração, possibilitando espaço para outras colocações. Como 
instrumento de coleta de dados utilizou-se roteiro com perguntas semiabertas direcionadas as pedagogas nas escolas, portanto é, de caráter descritivo.

A pesquisa foi realizada nos Municípios de Criciúma e Içara, com sete professoras pedagogas atuantes nos anos iniciais do ensino fundamental e educação infantil. Essas serão identificadas por, P1, P2, P3, P4, P5, P6 e P7. A escolha das professoras pedagogas ocorreu aleatoriamente, ora por meio de sugestão da orientadora desse artigo, ora por indicação de colegas. Ainda sobre as entrevistadas, importa saber que três delas, P7, P6 e a P3 se graduaram na UNESC, e as P5, P4, P2 e a P1 em modalidade de ensino à distância, todas estão atuando no magistério.

Após as entrevistas finalizadas, os dados coletados foram confrontados com o referencial teórico adotado a fim de responder ao problema da pesquisa. Para a apresentação e análise de dados optou-se em separar em duas categorias, nomeadas como: Formação inicial e continuada: uma trajetória de construção e reconstrução e, Didática e sua interface com a formação pedagógica.

\subsection{Formação inicial e continuada: uma trajetória de construção e reconstrução.}

A formação das entrevistadas ocorreu no período entre 2014 e 2016, todas são graduadas em Pedagogia e possuem formação continuada na área. Verificou-se que as professoras pedagogas P1, P2, P4, P5, e P6 estão atuando há dois anos, a P3 há um ano e a P7 há quatro anos.

A respeito de formação continuada se faz necessário lembrar que, essa formação deve dar aporte as dificuldades diárias dos professores, não necessitando ser realizada por causas externas a profissão, sendo assim, deve ocorrer por meio de "muito estudo, muita teoria, muita reflexão sobre sua prática” (LIBÂNEO,1998, p. 2).

Nesse sentido, chamou atenção o fato de que das sete pedagogas entrevistadas somente as professoras P4 e P6 buscaram a formação continuada para suprir dificuldades encontradas em sala de aula. As demais, como exemplo a professora P3 diz que, "eu escolhi fazer a pós a distância por ser mais rápido e contar pontuação para a escolha de vaga". Notase, que a busca por formação continuada por parte da maioria das entrevistadas ocorreu por

Saberes Pedagógicos, Criciúma, v. 4, nº 1, janeiro/abril 2020.- Curso de Pedagogia- UNESC 
motivos antagônicos ao que Libâneo (1998) considera ser importante na promoção dessa formação. A procura ocorreu para gerar maior pontuação no processo seletivo de oferta de vagas para a docência, conhecido como admissão em caráter temporário - ACT.

Segundo a pedagoga, "quando vai se fazer a prova para ACT, o número de curso que você tiver te dá mais pontos, ai você se sai um pouco melhor”. Diante desta fala é possível inferir que, para professora entrevistada não importa muito se o investimento feito vai ou não contribuir para a sua formação, o importante é que vai possibilitar uma melhor classificação na seleção.

Quanto ao fato de sentirem-se preparadas após graduação a exercerem a função de pedagogas, somente as professoras P6 e P7 responderam positivamente. A professora P6 diz que "Sim, pois uso muito do que aprendi, eu consigo usar na minha prática pedagógica, principalmente no âmbito do desenvolvimento humano mesmo, isso me ajuda bastante" e a professora P7 diz que, "Sim, deu o suporte inicial".

As professoras P1, P2, P3, P4 e P5, declaram que a graduação parece distanciar-se do dia a dia escolar e com isso elas não se sentiram preparadas para exercerem a função de pedagogas. Nesse sentido é compreensível a fala das pedagogas acima citadas, uma vez que, o sentimento de estar apto para ser professor não necessariamente desenvolve-se somente no espaço de formação inicial. Assim, Tardif (2002, p. 61) afirma, “[...] como vemos, os saberes que servem de base para o ensino, tais como são vistos pelos professores, não se limitam a conteúdos bem circunscritos que dependem de um conhecimento especializado".

Entende-se, portanto, a graduação como parte da construção profissional, contudo não é o fim. O sentir-se preparada não se dá pela passagem na graduação, mas a partir dela, em contato com a realidade de cada situação, com a troca de "experiências de trabalho" e por meio de formação continuada, tais fatores, vão constituindo o professor/professora.

Constatou-se ainda, que as pedagogas $\mathrm{P} 1$ e P4, não encontraram auxilio para suas dificuldades, as professoras P2, P3 e P5 encontram ajuda de colegas, já as professoras P6 e P7 encontraram suporte por meio da orientação pedagógica da escola e também da internet. Quanto ao uso da internet como ferramenta de suporte, fica a questão colocada por Pimenta (2013, p.10), em que a autora dá ênfase ao fato de que refletir acerca dos "[...] processos que operam na formação do conhecimento dos alunos." Em consequência disso, a busca por

Saberes Pedagógicos, Criciúma, v. 4, nº1, janeiro/abril 2020.- Curso de Pedagogia- UNESC 


\section{SABERES PEDAGÓGICOS}

Revista do Curso de Graduaçāo de Pedagogia - Unesc

ISSN 2526-4559

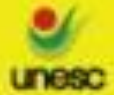

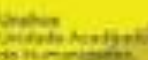

recurso para superar suas dificuldades, deve ser algo realizado com critério e com objetivo único, a apropriação do conhecimento dos alunos. Caso contrário, pode-se cair na armadilha da tendência tecnicista apontada por Libâneo (1993), em que se prioriza uma sequência de exercícios repetidos e memorização de conceitos, sem levar em conta os processos cognitivos dos alunos.

Com isto, percebeu-se que a formação inicial, foi o ponto de partida para habilitar as professoras a exercerem sua função, necessitando dar continuidade na formação, tanto para atualizar conhecimentos, como também para descobrir novas práticas, técnicas, maneiras, enfim, formas de superar os obstáculos.

Vale retomar, que o sentir-se preparada é algo subjetivo. Todavia observou-se que a medida que as pedagogas entrevistadas (P3, P5, P6 e P7) iriam tendo mais tempo em sala de aula, menos inseguras sentiam-se em relação a realidade escolar. Porém, a experiência de sala de aula não supria suas inquietações acerca do ensino/aprendizagem dos alunos, isso pode ser identificado na fala da professora P6, onde afirma que "existe uma grande dificuldade de ensino/aprendizagem que as escolas vêm vivenciando".

Nesse sentido, os autores, mencionados no referencial teórico, Libâneo (1993), (1998), (2001), Nóvoa (2009), Nóvoa e Vieira (2017) e Tardif (2002), apontam a relevância dos profissionais estarem em constante formação. Em relação ensino/aprendizagem, vale acrescentar o pensamento de Nóvoa e Vieira (2017), que entendem que o modo de trabalho do educador pode ocorrer por meio do compartilhamento de ideias com os demais professores. Deve-se pensar em conjunto, sobre diferentes atividades que concilie momentos de trabalho individual e outros coletivos. Os autores sugerem estreitamento do "trabalho científico (curiosidade, pesquisa, descoberta, sistematização)", na busca para superar a dificuldade de ensino/aprendizagem ainda tão presente na realidade escolar. (NÓVOA e VIEIRA ,2017, p.27).

Entende-se ser improvável a dicotomia entre profissional e pessoal, bem como já afirmava Tardif (2002), no decorrer das entrevistas pode-se descrever quão difícil foi para as pedagogas entrevistadas, chegarem em um ambiente em que relações estavam consolidadas, onde os professores haviam criado grupos, e dessa forma não davam abertura as recémchegadas. A exemplo da fala da professora P2, "Quando a gente chega na escola tu vai te

Saberes Pedagógicos, Criciúma, v. 4, nº 1, janeiro/abril 2020.- Curso de Pedagogia- UNESC 
sentir estranha, os efetivos todos os anos estão juntos, mas as crianças não, elas te recebem com amor". Também se observou na fala da professora P1, “Assim, nós quando estamos entrando, te vira com a turma".

De modo que, para Nóvoa e Vieira (2017, p.28), é o início da vida profissional do educador que determina a "relação com a profissão, para fortalecer a nossa identidade profissional e para afirmar uma posição junto aos colegas mais velhos". De acordo com os autores, entende-se que, a conduta de não importarem-se com as recém-chegadas, pode vir a interferir no trabalho pedagógico das professoras. Nesse caso, há de se questionar se tal atitude não prejudicaria o processo de ensino/aprendizagem dos educandos?

\subsection{Didática e sua interface com a formação pedagógica.}

Compreende-se a didática como ferramenta mediadora entre os conhecimentos científicos e a prática educativa (LIBÂNEO, 1993). Assim, entendeu-se ser relevante discutir as possíveis dificuldades em elaborar o plano de aula que levasse em conta o ano escolar dos alunos, a heterogeneidade da turma, a seleção de conteúdos, a proposta curricular e outros.

A esse respeito todas as entrevistadas relataram que sentiram dificuldades em elaborar um plano de aula que atendesse as especificidades mencionadas acima. A professora P1 alega ser por conta de muita teoria na graduação, mas pouca prática no sentido de planejamento de aula. As professoras P2, P5 e P7 pautaram suas dificuldades na falta de material (livro didático) para planejarem suas aulas. Já a professora P3 atribui suas dificuldades ao fato de ter medo que seu planejamento seja reprovado por parte da coordenadora pedagógica da escola e, quanto a professora P4, essa diz ter muita dificuldade por sentir que ao chegar na escola, não há cuidado da coordenação pedagógica e da gestão em relação as professoras recém-chegadas. Já a professora P6 afirma que, "antes da graduação sim, após a formação tenho apoio da coordenação pedagógica da escola que trabalho, porque trabalho somente em instituição particular, então tem sempre a coordenadora pedagógica”.

Há muitos aspectos que precisam ser analisados a partir das declarações das entrevistadas. Primeiro, destaca-se a ação da didática que direcionam o pensamento e as atividades das professoras. Assim, é preciso refletir qual o papel da didática nessa formação,

Saberes Pedagógicos, Criciúma, v. 4, n¹, janeiro/abril 2020.- Curso de Pedagogia- UNESC 
uma vez que a concepção teórica é a expressão de uma determinada prática e não, qualquer prática. Então, quando se afirma que "há muita teoria e pouca prática", "quando há falta de materiais livros didáticos", poder-se-ia pensar que as entrevistadas estão procurando por "modelos ou receitas pedagógicas, prontas"? Ou, porque ainda não entenderam que as tendências pedagógicas estudadas na sua graduação, também se referem à forma de perceber o ensino e aprendizagem?

Deste ponto de vista, a didática, na perspectiva de Pimenta (2013), tem a função de identificar as transformações sociais que estão ocorrendo, para que seja possível dar sentido ao que está sendo ensinado e acima de tudo, promover a aprendizagem dos alunos. Assim, a didática

[...] como campo específico de conhecimento, tem uma responsabilidade social de acompanhar e refletir as mudanças que ocorrem no mundo e dar respostas para a ressignificação dos processos de ensino na perspectiva da aprendizagem do aluno. (PIMENTA, 2013, p.150).

Esta realidade, de desconhecimento do papel da didática, mostra-se preocupante, pois, para Pimenta (2013) a didática pode ser vista como um saber experiencial, uma vez que possibilita articular a realidade com o conteúdo ensinado proporcionando sentido real e significativo aos educandos.

Outro ponto a ser refletido, diz respeito ao apoio pedagógico que as recémformadas recebem ao chegarem à escola. Como diz Freire (1996) em seus livros sobre educação, é necessário ter clareza das incompletudes dos saberes pedagógicos, ou seja, sendo seres incompletos, é na busca que se possibilita encontrar a melhor forma de ser e agir e assim estar em constante procura de aperfeiçoamento.

Percebeu-se ainda que as entrevistadas pouco sabiam acerca das tendências pedagógicas, tendo visto a confusão em explicar em qual tendência planejavam seu trabalho. A professora P2 foi clara ao dizer que, não se recordava, a professora P5 diz, "não sei dizer o que é”, as professoras P1, P4 entendem que não conseguiram se desvincular da tendência tradicional porque ambas "passam no quadro".

Estas afirmativas provocaram reflexões, pois a pesquisa fundamenta-se em autores que destacam a importância de se ter consciência que o trabalho pedagógico está Saberes Pedagógicos, Criciúma, v. 4, nº 1, janeiro/abril 2020.- Curso de Pedagogia- UNESC 


\section{SABERES PEDAGÓGICOS}

Revista do Curso de Graduaçāo de Pedagogia - Unesc

ISSN 2526-4559

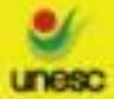

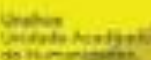

sempre fundamentado em tendências pedagógicas de educação. Com isso compreender determinadas tendências é essencial para a atuação profissional, as escolas nas quais as pesquisadas estão inseridas, estão fundamentadas em uma proposta curricular pautada na tendência crítico social dos conteúdos. Se as entrevistadas desconhecem os conceitos das tendências, com que base pedagógica desenvolvem seus trabalhos?

De acordo com Libâneo (2001) percebe-se a relevância em conhecer as tendências, pois a partir desta é possível identificar se o professor entende a educação em uma perspectiva liberal, assim, estará contribuindo para manter a realidade posta, ou se assume um posicionamento político, atribuindo a educação o papel de transformação social e, desta forma, pautando-se em uma tendência progressista.

Quanto à professora P3, ela diz trabalhar com as tendências "critico cultural, tendência da instituição porque a gente trabalha encima da realidade da comunidade, é visível a gente tem que trabalhar em cima da realidade deles e a libertária né, eu não uso fila, porque meus alunos têm 4 anos, então eu não obrigo, eu deixo por eles".

As professoras P6 e P7 alegam trabalhar com a tendência crítico social dos conteúdos, sendo que a professora P6 expressa confusão ao falar que, "o planejamento é dentro da tendência crítico social dos conteúdos porque trabalho com educação infantil e então confecciono muito material para as crianças", e pôr fim a professora P7 diz que, "busco construir meu trabalho na tendência crítico social dos conteúdos, mas não sei se o tempo todo".

Tais afirmativas não representam o referencial teórico adotado, sendo que para Libâneo (2001) a tendência crítico social dos conteúdos objetiva o questionamento dos fatos históricos em relação aos dias atuais, diz que o aluno deve ser participativo e questionador e isso, não significa não fazer uso de materiais didáticos prontos ou permitir que falte a organização em sala de aula. Pelo contrário, entende-se ser uma tendência que instigue o educando a correlacionar a atualidades, dos acontecimentos com fatos passados e assim, buscar formas de transformar dada situação.

Com relação à tendência tradicional, na qual as professoras pedagogas P1 e P4, afirmam que trabalham pelo fato de "passarem no quadro", mais uma vez encontra-se disparidades se comparada aos pressupostos de Libâneo (1993), uma vez que esta tendência

Saberes Pedagógicos, Criciúma, v. 4, nº 1, janeiro/abril 2020.- Curso de Pedagogia- UNESC 
pauta-se na transmissão de conteúdo, por vezes, sem conexão com a realidade vivenciada por seus alunos, onde o professor é autoridade, utilizando-se de castigos, com foco na memorização. Assim, percebe-se que Libâneo (1993), não faz nenhuma afirmação quanto a passar no quadro. Assim, acredita-se que, a definição de tendência que o educador adota, demonstra-se na forma com que ele planeja suas aulas, na maneira que ele acredita que o aluno aprende e ainda, ao que ou a quem, ele atribui a aprendizagem do aluno. Acredita-se que são essas características que revelam qual tendência o professor realmente pauta seu trabalho.

Ainda sobre tendências pedagógicas, vale a reflexão sobre a concepção que Libâneo (1993, p.65) faz acerca da tendência tradicional, onde ele diz que, as práticas adotadas nas escolas "empobrece até as boas intenções da Pedagogia Tradicional que pretendia, com seus métodos, a transmissão da cultura geral, isto é, das grandes descobertas da humanidade, e a formação do raciocínio, o treino da mente.” (LIBÂNEO 1993, p.65). Do mesmo modo, que a professora P3 afirma não ser tradicional, pois "não uso fila". Logo, percebe-se que não há uma clareza em relação ao entendimento de que seja de fato a educação tradicional.

Assim, percebe-se a necessidade de maior apropriação dos conceitos de tendências pedagógicas durante o processo de formação inicial, entendendo que o conhecimento de tendência pedagógica possibilita o professor pautar seu planejamento de acordo com a proposta da escola que ele está inserido, bem como, alcançar os objetivos propostos no projeto político pedagógico.

\section{CONCLUSÃO}

A escolha desse tema deu-se por situações vivenciadas em escolas, tendo como foco o professor. A partir desse momento um novo olhar começa se desvelar acerca da construção da formação docente.

Dessa forma, à medida que se aprofundavam as leituras, as inquietações iniciais começaram a encontrar respostas, até chegar o momento de entrevistar as professoras pedagogas. No primeiro contato com as professoras entrevistadas, pode-se perceber a 
preocupação de serem analisadas e julgadas. Porém, a partir do momento que foi explicado que o objetivo da pesquisa era contribuir com a formação docente, todas foram receptivas, assim, aos poucos, foram demostrando entre uma resposta e outra o quanto o início da vida profissional é delicado.

Percebeu-se que todas as pedagogas, procuraram dar continuidade em sua formação, mas observou-se que não houve, pela maioria das pedagogas, uma escolha pensada, refletida e discutida junto aos seus pares, a respeito das dificuldades surgidas no dia a dia do seu trabalho. Até porque, contatou-se, não haver espaço para as pedagogas entrevistadas, colocarem suas dificuldades. Entendeu-se ser bem difícil uma discussão onde possa ser problematizado o tema formação continuada.

Não se pretende responsabilizar as instituições formadoras, as professoras efetivas e/ou gestão, nem tampouco as instituições de formação continuada. Contudo objetiva-se problematizar a construção da formação docente das licenciadas em Pedagogia, sendo que constatou-se ser o período inicial de formação um momento delicado, como foi colocado por parte das pedagogas.

Observou-se ainda, que para além das dificuldades decorrentes do início de carreira, as pedagogas têm que lidar com a falta de acolhimento, com o distanciamento da realidade escolar e o ideal de escola, com a falta de material didático e suporte pedagógico.

Em relação à concepção de tendência pedagógica pode-se identificar, que trata-se, de uma realidade preocupante, pois as entrevistadas demonstraram pouco conhecimento sobre a temática. Com isso surge à dúvida, é possível estar inserida em um contexto escolar que afirma seguir a tendência critico social dos conteúdos e, no entanto, não compreender o que de fato representa cada uma das tendências pedagógicas e suas consequências futuras?

Percebeu-se a necessidade de promover diálogos que busquem salientar o papel da educação, onde os professores possam refletir se a prática pedagógica adotada em seu trabalho visa manter a realidade social vigente ou se, irão desenvolver um trabalho adotando uma prática que esteja em conformidade com a tendência pedagógica vigente na escola, e assim, trabalhe para promover a superação de uma realidade desigual e excludente, evidenciando seu papel emancipatório e libertador. Nessa perspectiva, credita-se ao 
conhecimento uma possibilidade de romper paradigmas a fim de contribuir para formação integral do sujeito.

Nota-se a importância de salientar que é possível mudar o cenário exposto, mas isso requer um trabalho mútuo, inicialmente por parte das intuições formadoras, adotando a práxis no período de graduação, possibilitando maior tempo de permanência das acadêmicas dentro do ambiente escolar. Tais possibilidades já podem ser vistas em programas federais como PIBID e Residência Pedagógica, que buscam inserir os acadêmicos em contextos escolares ampliando e qualificando a formação inicial, mas ainda são incipientes e novos.

Percebe-se relevante a conscientização por parte dos professores mais experientes, da gestão/coordenação, em relação ao início da entrada desse profissional na carreira docente, visto que, o período de iniciação da carreira é delicado, e permeado de inseguranças, assim entende-se que, apoiar esses profissionais recém-formados é fundamental para o sucesso na carreira docente.

Enfim, por acreditar que a educação tem condições de contribuir de maneira significava com a transformação da realidade, é que se fez essa pesquisa. Desse modo pretende-se contribuir para uma reflexão por parte dos envolvidos na educação, almejando implicações no processo de formação docente. Busca-se ainda, fazer com que esta pesquisa venha somar para a construção da formação docente, trazendo ganhos, tanto para os docentes como também para sociedade.

\section{REFERÊNCIAS}

FREIRE, Paulo. Pedagogia da Autonomia Saberes Necessários à Prática Educativa. São Paulo: Paz e Terra, 1996.

GIL, Antônio Carlos. Como elaborar projetos de pesquisa. 4 ed. São Paulo: Atlas, 2002.

LIBÂNEO, José Carlos. Didática. São Paulo: Cortez, 1993.

LIBÂNEO, José Carlos. Congressos, encontros, seminários de educação: espaço de desenvolvimento profissional ou mercado de entusiasmo?. Revista de Educação AEC, Ano 27 - nº 109, out/dez 1998. Disponível em AEC do Brasil www.aecbrasil.org.br Acesso em 09 maio 2018. 
LIBÂNEO, José Carlos. Democratização da escola pública: A pedagogia crítico-social dos conteúdos. 17 ed. São Paulo: Ed. Loyola, 2001. 149 p. ISBN 85-15-00181-0.

NÓVOA, Antônio. Para uma formação de professores construída dentro da profissão. Revista Educacion. Lisboa Portugal: 2009.

Disponível em <www.revistaeducacion.educacion.es/re350/re350_09porpdf> Acesso em 13 maio 2018

NÓVOA, A.; VIEIRA, P. Um alfabeto da formação de professores. Crítica Educativa, Sorocaba, SP, v. 3, n. 2 - Especial, p. 21-49, jan./jun.2017. Disponível em file:///C:/Users/Usu\%C3\%A1rio/Downloads/217-1345-3-PB\%20(1).pdf Acessado em 18 maio 2018.

PIMENTA, Selma Gariido et al. A construção da didática no GT Didática - análise de seus referenciais. Revista Brasileira de Educação, Rio de Janeiro, v.18 n.52, jan. /mar. 2013. Disponível em: http://www.scielo.br/pdf/rbedu/v18n52/09.pdf Acesso em: 18 maio 2018.

SANTA CATARINA. Proposta Curricular de Santa Catarina: formação integral na educação básica. Estado de Santa Catarina, Secretaria de Estado da Educação, 2014. Disponível em:file:///C:/Users/Usu\%C3\%A1rio/Downloads/Proposta_Curricular_final.pdf. Acesso em: 14 out. 2018.

TARDIF, Maurice. Saberes docente e formação profissional. Petrópolis, Rio de Janeiro: Vozes, 2002. 